\title{
Self-citation policies and journal self- citation rate among Critical Care Medicine journals
}

\author{
Filippo Sanfilippo ${ }^{1 *} \mathbb{D}$, Stefano Tigano ${ }^{2}$, Alberto Morgana ${ }^{3}$, Paolo Murabito ${ }^{1,2}$ and Marinella Astuto ${ }^{1,2}$
}

\begin{abstract}
Background: Inappropriate authors' self-citation (A-SC) is a growing mal-practice possibly boosted by the raising importance given to author's metrics. Similarly, also excessive journals' self-citation (J-SC) practice may factitiously influence journal's metrics (impact factor, IF). Evaluating the appropriateness of each self-citation remains challenging.

Main body: We evaluated the presence of policies discouraging A-SC in Critical Care Medicine (CCM) journals with IF. We also calculated the J-SC rate of these journals. In order to evaluate if J-SC rates are influenced by the focus of interest of CCM journals, we separated them in three sub-categories ("multidisciplinary", "broad" or "topic-specific" CCM journals).

We analyzed 35 CCM journals and only 5 (14.3\%) discouraged excessive and inappropriate A-SC. The median IF was higher in CCM journals with A-SC policies [4.1 (3-12)] as compared to those without [2.5 (2-3.5); $p=0.02]$. The J-SC rate was highly variable ( $0-35.4 \%)$, and not influenced by the presence of A-SC policies $(p=0.32)$. However, J-SC rate was different according to the focus of interest $(p=0.01)$ : in particular, it was higher in "topic-specific" CCM journals [15.3 (8.8-23.3\%)], followed by "broad" CCM [11.8 (4.8-17.9\%)] and "multidisciplinary" journals [6.1 (3.69.1\%)].
\end{abstract}

Conclusions: A limited number of CCM journals have policies for limiting A-SC, and these have higher IF. The J-SC rate among CCM journals is highly variable and higher in "topic-specific" interest CCM journals. Excluding selfreferencing practice from scientific metrics calculation could be valuable to tackle this scientific malpractice.

Keywords: Intensive Care, Authors, Citations, Impact factor, Journals, Policies, Self-citations

\section{Background}

Inappropriate authors' self-promoting is a growing mal-practice [1], possibly prompted by the mounting scientific importance of author's metrics. We recently surveyed the submission guidelines of Anaesthesiology journals for the presence of policies discouraging author self-citations (A-SC) [2]. In parallel, we also evaluated the journals' self-citation (J-SC) practice,

\footnotetext{
* Correspondence: filipposanfi@yahoo.it

'Department of Anaesthesia and Intensive Care, A.O.U., "Policlinico-Vittorio Emanuele" University Hospital, via S. Sofia 78, 95100 Catania, Italy Full list of author information is available at the end of the article
}

which may hinder attempts of the Editorial Board to increase the journal impact factor (IF).

Although excessive and inappropriate A-SC and J-SC are two independent forms of suboptimal academic practice that have not yet received enough attention, it must be clear from the beginning that not all A-SC and $\mathrm{J}$-SC are synonymous of malpractice.

In the present study, we evaluated the J-SC rate among the Critical Care Medicine (CCM) journals and possible factors influencing it, as well as the presence of policies regarding A-SC in these journals. 


\section{Methods}

On the 30 October 2020, we evaluated the presence of policies discouraging A-SC in the submission guidelines of CCM journals selected from the InCites Journal Citation Reports 2019 (Clarivate Analytics ${ }^{\oplus}$ ) [3]. The J-SC rate was evaluated according to the following formula:

$$
\text { JSC rate }=\frac{\text { IF }- \text { IF without self citations }}{\text { IF }}
$$

Our previous investigation suggested that journals focusing on a specific topic of the discipline had a trend towards higher J-SC rate $(25 \%$ vs $7 \%$ as compared to those with broad interest; $p=0.06$ ) [2]. Accordingly, we performed a secondary analysis separating CCM journals in three sub-categories: (1) "multidisciplinary journals" (defined as journals focusing not only on CCM but also on other disciplines as Anaesthesiology, Respiratory Medicine, etc.); (2) "broad interest" CCM journals (defined as those publishing on several aspects of the discipline); (3) "topic-specific" CCM journals (focusing on specific topics of CCM interest). We evaluated also if $\mathrm{J}-\mathrm{SC}$ is influenced by presence of A-SC policies.

Continuous variables are presented as median (25th-75th percentile), categorical variables as numbers/percentage. Mann-Whitney $U$ test or Kruskal-Wallis test for unrelated samples were performed according to the number of groups. Tests were two-sided; $p<0.05$ was considered statistically significant.

\section{Results}

A total of 36 CCM journals were found but we removed Human Gene Therapy Clinical Development as its scope clearly falls outside the CCM. Therefore, 35 journals were included. In Table 1, we report J-SC rates and presence of policies regarding A-SC. Five journals (14.3\%) discouraged "excessive and inappropriate" self-citations; none proposed an A-SC cut-off. The median IF of CCM journals was $2.7(2.1-3.8)$ and was higher in CCM journals with policies on A-SC[4.1 (3-12)] as compared to those without [2.5 (2-3.5); $p=0.02]$.

The J-SC rate was highly variable $(0-35.4 \%)$ with median $8.8 \%(5.1-17.4 \%)$ and was not different between journals with or without A-SC policies [8.1\% (5.1-9.5\%) vs $9.4 \%$ (5-18.7\%), respectively; $p=0.32$ ].

CCM journals were sub-categorized as follows: 11 were considered "multidisciplinary" (Table 1: rank 1-34-11-18-20-27-28-29-34-35), 14 were classified as "broad interest" (rank 2-5-6-8-9-12-13-15-19-21-22-23-25-31), and 10 were "topic-specific" CCM journals (rank 7-1014-16-17-24-26-30-32-33). We found significantly different J-SC rate according to the journal interest $(p=0.01)$, with higher values in "topic-specific" [15.3 (8.8-23.3\%)] followed by "broad interest" [11.8 (4.8-17.9\%)] and "multidisciplinary" journals [6.1 (3.6-9.1\%)]. Conversely, the IF was not different between journals according to sub-categories $(p=0.35)$ : "topic-specific" [2.4 (1.4-3.2)], "broad interest" [2.5 (1.5-8.3)] and "multidisciplinary" journals $[3.0(2.3-4.7)]$. The J-SC rate was not significantly influenced by the presence of policies on A-SC $(8.1 \%$ [5.1-9.5\%]) or not (9.4\% [5-18.7\%]; $p=0.32)$.

\section{Discussion}

Our investigations follows a similar assessment conducted in Anaesthesiology journals [2] and found lower prevalence of A-SC policies among CCM journals as compared to Anaesthesiology ones (14\% vs $22 \%)$. This finding reinforces our belief that the argument of limiting the malpractice of inappropriate selfreferencing is still at embryonic level. Several forms of research misconduct (fabrication, falsification, plagiarism, ghost-writing) have been recognized [4, 5], but "inappropriate self-citation" and "citation farms" have not yet received widespread editorial attention. In our opinion, it is urgent to embrace a debate on the best approach for limiting inappropriate selfreferencing, keeping in mind that it remains challenging to define the appropriateness of each A-SC [6] and that a single cut-off is unlikely to fit all the manuscript types. Interestingly, we found a significantly higher IF in CCM journal with policies on A-SC, and this may be a marker of higher publishing standards. Such finding is new, as we did not report differences in IF among Anaesthesiology journals according to presence of A-SC policies [2]. This result may support larger investigations, as the findings of single disciplines are likely influenced by a reduced sample size investigated.

The J-SC rate and its variability were similar between CCM (8.8\%, range $0-35.4 \%)$ and Anaesthesiology journals $(8.4 \%$, range $1.4-37.2 \%)$, and J-SC rate was not different according to the presence of A-SC policies.

Several factors may influence J-SC rate. Although it is possible that an excessive $\mathrm{J}-\mathrm{SC}$ rate may sometimes hinder a sort of editorial malpractice (requests to reference specific articles with the aim to boost IF) [7], this is difficult to assess. Conversely, it must be noted that J-SC rate is also increased by editorials and commentaries introducing the highlights of important articles published by the journal. Therefore, the interpretation of J-SC rate is another challenging aspect of self-promoting. Importantly, whilst the presence of A$\mathrm{SC}$ policies does not seem to influence the J-SC rate, our secondary analysis showed that the focus of interest of CCM journals is a factor significantly influencing the J-SC rate. Indeed, CCM journals with narrower focus of interest had significantly higher J-SC as compared 
Table 1 List of Critical Care Medicine journals according to their rank in Journal Citation Report 2019. For each journal we provide the following: Journal Rank and Full Title, Impact Factor (IF) and IF without self-citation (SC), Journal Self-Citation Rate (J-SC, year 2019), Publisher name, presence and description of policies on limiting SC. Each Journal's name contains a hyperlink to its "instruction to authors/submission guidelines" so that readers may check them

\begin{tabular}{|c|c|c|c|c|c|c|}
\hline \multicolumn{2}{|c|}{ Journal rank and full title } & \multirow{2}{*}{$\begin{array}{l}\text { IF } \\
25, \\
09\end{array}$} & \multirow{2}{*}{$\begin{array}{l}\text { IF } \\
\text { without } \\
\text { SC } \\
24,31\end{array}$} & \multirow{2}{*}{$\begin{array}{l}\text { J-SC } \\
\text { rate } \\
(2019)\end{array}$} & \multirow{2}{*}{$\begin{array}{l}\text { Publisher } \\
\text { Elsevier SCI LTD, Oxford, } \\
\text { England, }\end{array}$} & \multirow{2}{*}{$\begin{array}{l}\text { Policy description } \\
\text { None }\end{array}$} \\
\hline 1 & $\begin{array}{l}\text { Lancet Respiratory } \\
\text { Medicine }\end{array}$ & & & & & \\
\hline 2 & Intensive Care Medicine & $\begin{array}{l}17 \\
68\end{array}$ & 15,79 & 10,7 & Springer, New York, USA & $\begin{array}{l}\text { Research articles and non-research articles (e.g. opinion, re- } \\
\text { view, and commentary articles) must cite appropriate and } \\
\text { relevant literature in support of the claims made. Excessive } \\
\text { and inappropriate self-citation or coordinated efforts } \\
\text { among several authors to collectively self-cite is strongly } \\
\text { discouraged. }\end{array}$ \\
\hline 3 & $\begin{array}{l}\text { American Journal of } \\
\text { Respiratory and Critical } \\
\text { Care Medicine }\end{array}$ & $\begin{array}{l}17 \\
45\end{array}$ & 15,95 & 8,6 & $\begin{array}{l}\text { Amer Thoracic Soc, New York, } \\
\text { USA }\end{array}$ & None \\
\hline 4 & Chest & $\begin{array}{l}8 \\
31\end{array}$ & 7,91 & 4,8 & $\begin{array}{l}\text { Amer Coll Chest Physicians, } \\
\text { Northbrook, USA }\end{array}$ & None \\
\hline 5 & Critical Care Medicine & $\begin{array}{l}7, \\
41\end{array}$ & 6,78 & 8,6 & $\begin{array}{l}\text { Lippincott Williams \& Wilkins, } \\
\text { Philadelphia, USA }\end{array}$ & None \\
\hline
\end{tabular}

6 Critical Care

$6, \quad 5,89$

BioMed Central LTD, London, England

7 Resuscitation

$4, \quad 2,85$

21

8 Annals of Intensive Care

$4, \quad 3,90$

Elsevier Ireland Ltd., Elsevier House, Clare, Ireland

\begin{tabular}{|c|c|c|}
\hline & Critical Care Clinics & $\begin{array}{l}3, \\
80\end{array}$ \\
\hline 0 & Journal of Neurotrauma & $\begin{array}{l}3, \\
79\end{array}$ \\
\hline & $\begin{array}{l}\text { Journal of Trauma and } \\
\text { Acute Care Surgery }\end{array}$ & $\begin{array}{l}3, \\
38\end{array}$ \\
\hline & $\begin{array}{l}\text { Journal of Intensive Care } \\
\text { Medicine }\end{array}$ & $\begin{array}{l}3, \\
14\end{array}$ \\
\hline & Journal of Intensive Care & 3 \\
\hline
\end{tabular}

10

14 Shock

$2, \quad 2,71$

96
0

W B Saunders Co-Elsevier Inc., Philadelphia, USA

Mary Ann Liebert Inc., New Rochelle, USA

John Ewers

Wolters Kluwer

Baltimore, USA

Sage Publications Inc, Thousand Oaks, USA

BMC, Crinan St., London, England
Lippincott Williams \& Wilkins, Philadelphia, USA
15 Current Opinion in Critical Care
Lippincott Williams \& Wilkins, Philadelphia, USA
Research articles and non-research articles (e.g. opinion, review, and commentary articles) must cite appropriate and relevant literature in support of the claims made. Excessive and inappropriate self-citation or coordinated efforts among several authors to collectively self-cite is strongly discouraged.

None

Research articles and non-research articles (e.g. Opinion, Review, and Commentary articles) must cite appropriate and relevant literature in support of the claims made. Excessive and inappropriate self-citation or coordinated efforts among several authors to collectively self-cite is strongly discouraged.

None

None

None

None

Research articles and non-research articles (e.g. Opinion, Review, and Commentary articles) must cite appropriate and relevant literature in support of the claims made. Excessive and inappropriate self-citation or coordinated efforts among several authors to collectively self-cite is strongly discouraged.Authors should not preferentially cite their own or their friends', peers', or institution's publications.

Research articles and non-research articles (e.g. Opinion, Review and Commentary articles) must cite appropriate and relevant literature in support of the claims made. Excessive and inappropriate self-citation or coordinate efforts among several authors to collectively self-cite is strongly discouraged

None 
Table 1 List of Critical Care Medicine journals according to their rank in Journal Citation Report 2019. For each journal we provide the following: Journal Rank and Full Title, Impact Factor (IF) and IF without self-citation (SC), Journal Self-Citation Rate (J-SC, year 2019), Publisher name, presence and description of policies on limiting SC. Each Journal's name contains a hyperlink to its "instruction to authors/submission guidelines" so that readers may check them (Continued)

\begin{tabular}{|c|c|c|c|c|c|c|}
\hline \multicolumn{2}{|r|}{ Journal rank and full title } & \multirow{2}{*}{$\begin{array}{l}\text { IF } \\
2, \\
5\end{array}$} & \multirow{2}{*}{$\begin{array}{l}\text { IF } \\
\text { without } \\
\text { SC } \\
2,26\end{array}$} & \multirow{2}{*}{$\begin{array}{l}\text { J-SC } \\
\text { rate } \\
(2019)\end{array}$} & \multirow{2}{*}{$\begin{array}{l}\text { Publisher } \\
\text { Lippincott Williams \& Wilkins, } \\
\text { Philadelphia, USA }\end{array}$} & \multirow{2}{*}{$\begin{array}{l}\text { Policy description } \\
\text { None }\end{array}$} \\
\hline 16 & $\begin{array}{l}\text { Pediatric Critical Care } \\
\text { Medicine }\end{array}$ & & & & & \\
\hline 17 & Neurocritical Care & $\begin{array}{l}2 \\
72\end{array}$ & 2,45 & 10 & Humana Press Inc., Totowa, USA & None \\
\hline 18 & $\begin{array}{l}\text { Anaesthesia Critical Care } \\
\& \text { Pain Medicine }\end{array}$ & $\begin{array}{l}2 \\
71\end{array}$ & 2,32 & 14,1 & $\begin{array}{l}\text { Elsevier France-Editions Scientifi- } \\
\text { ques Medicales Elsevier, Issy-Les- } \\
\text { Moulineaux, France }\end{array}$ & None \\
\hline 19 & Journal of Critical Care & $\begin{array}{l}2 \\
68\end{array}$ & 2,55 & 5,1 & $\begin{array}{l}\text { W B Saunders CO-Elsevier Inc., } \\
\text { Philadelphia, USA, }\end{array}$ & None \\
\hline 20 & Minerva Anestesiologica & $\begin{array}{l}2 \\
50\end{array}$ & 1,61 & 35,4 & $\begin{array}{l}\text { Edizioni Minerva Medica, Turin, } \\
\text { Italy }\end{array}$ & None \\
\hline 21 & $\begin{array}{l}\text { Critical Care and } \\
\text { Resuscitation }\end{array}$ & $\begin{array}{l}2 \\
49\end{array}$ & 2,32 & 6,9 & $\begin{array}{l}\text { Australasian Med Publ Co Ltd., } \\
\text { Australia }\end{array}$ & None \\
\hline 22 & Medicina Intensiva & $\begin{array}{l}2 \\
36\end{array}$ & 1,71 & 27,8 & $\begin{array}{l}\text { Elsevier Espana Slu, Barcelona, } \\
\text { Spain }\end{array}$ & None \\
\hline 23 & Australian Critical Care & $\begin{array}{l}2 \\
21\end{array}$ & 1,89 & 14,5 & $\begin{array}{l}\text { Elsevier Science Inc., New York, } \\
\text { USA }\end{array}$ & None \\
\hline 24 & $\begin{array}{l}\text { Injury-International } \\
\text { Journal of the Care of } \\
\text { the Injured }\end{array}$ & $\begin{array}{l}2 \\
11\end{array}$ & 1,79 & 14,9 & $\begin{array}{l}\text { Elsevier Sci Ltd., The Boulevard, } \\
\text { Oxford, England }\end{array}$ & None \\
\hline 25 & $\begin{array}{l}\text { American Journal of } \\
\text { Critical Care }\end{array}$ & $\begin{array}{l}2 \\
10\end{array}$ & 1,96 & 6,8 & $\begin{array}{l}\text { Amer Assoc Critical Care Nurses, } \\
\text { Aliso Viejo, USA }\end{array}$ & None \\
\hline 26 & Burns & $\begin{array}{l}2 \\
07\end{array}$ & 1,62 & 21,5 & $\begin{array}{l}\text { Elsevier Sci Ltd., The Boulevard, } \\
\text { Oxford, England }\end{array}$ & None \\
\hline 27 & Respiratory Care & $\begin{array}{l}2 \\
07\end{array}$ & 1,71 & 17,4 & $\begin{array}{l}\text { Daedalus Enterprises Inc., Irving, } \\
\text { USA }\end{array}$ & None \\
\hline 28 & $\begin{array}{l}\text { Seminars in Respiratory } \\
\text { and Critical Care } \\
\text { Medicine }\end{array}$ & $\begin{array}{l}2 \\
03\end{array}$ & 1,97 & 2,8 & $\begin{array}{l}\text { Thieme Medical Publ Inc., New } \\
\text { York, USA }\end{array}$ & None \\
\hline 29 & $\begin{array}{l}\text { Anaesthesia and } \\
\text { Intensive Care }\end{array}$ & $\begin{array}{l}1 \\
54\end{array}$ & 1,36 & 11,8 & $\begin{array}{l}\text { Australian SOC Anaesthetists, } \\
\text { Edgecliff, Australia }\end{array}$ & None \\
\hline 30 & $\begin{array}{l}\text { Journal of Burn Care \& } \\
\text { Research }\end{array}$ & $\begin{array}{l}1 \\
53\end{array}$ & 1,29 & 15,7 & $\begin{array}{l}\text { Lippincott Williams \& Wilkins, } \\
\text { Philadelphia, USA }\end{array}$ & None \\
\hline 31 & Critical Care Nurse & $\begin{array}{l}1 \\
48\end{array}$ & 1,44 & 2,9 & $\begin{array}{l}\text { Amer Assoc Critical Care Nurses, } \\
\text { Aliso Viejo, USA }\end{array}$ & None \\
\hline 32 & $\begin{array}{l}\text { Therapeutic Hypothermia } \\
\text { and Temperature } \\
\text { Management }\end{array}$ & $\begin{array}{l}1 \\
18\end{array}$ & 0,84 & 28,7 & $\begin{array}{l}\text { Mary Ann Liebert, Inc., New } \\
\text { Rochelle, USA, NY }\end{array}$ & None \\
\hline 33 & $\begin{array}{l}\text { Journal of Trauma } \\
\text { Nursing }\end{array}$ & $\begin{array}{l}0 \\
87\end{array}$ & 0,80 & 8,8 & $\begin{array}{l}\text { Lippincott Williams \& Wilkins, } \\
\text { Philadelphia, USA }\end{array}$ & None \\
\hline 34 & $\begin{array}{l}\text { Anasthesiologie \& } \\
\text { Intensivmedizin }\end{array}$ & $\begin{array}{l}0 \\
84\end{array}$ & 0,58 & 30,4 & $\begin{array}{l}\text { Aktiv Druck \& Verlag GMBH, } \\
\text { Ebelsbach, Germany }\end{array}$ & None \\
\hline 35 & $\begin{array}{l}\text { Anasthesiologie } \\
\text { Intensivmedizin } \\
\text { Notfallmedizin } \\
\text { Schmerztherapie }\end{array}$ & $\begin{array}{l}0, \\
53\end{array}$ & 0,50 & 5,1 & $\begin{array}{l}\text { Georg Thieme Verlag KG, } \\
\text { Stuttgart, Germany }\end{array}$ & None \\
\hline
\end{tabular}


with "broad CCM interest" and "multidisciplinary" journals. Therefore, while a narrower focus of interest should not be regarded as justification for excessive selfpromoting, the interpretation of J-SC rates should be paired, among others, with critical estimation of the journal's scope. Conversely, we found that the focus of interest does not seem to influence the journal IFs.

Considering all the factors influencing the J-SC rates and also the difficulties in critically evaluating the appropriateness of each A-SC or J-SC, an option could be to calculate author's and journal's scientific metrics excluding self-citations. Doing so, inappropriate selfreferencing will become a useless practice. Importantly, Scopus $^{\bullet}$ and Web of Science ${ }^{\bullet}$ databases offer the opportunity to exclude A-SC when observing scientific metrics. Similarly, it is feasible to calculate the journal's IF without J-SC contribution (as shown in Table 1 in our study).

\section{Limitations}

Overall, our investigation on A-SC policies and J-SC rates over-simplifies complex issues, since we again reinforce that it is challenging to evaluate the appropriateness of each A-SC as well as to show editorial requests to add specific citations. Furthermore, the lack of policies regarding A-SC and the J-SC rate may be greater in "predatory journals" $[8,9]$. Another limitation of this study is that several journals publishing in the field of CCM were not included as not listed in the InCites Journal Citation Reports. For instance, several Anaesthesiology journals have dedicated sections on CCM.

\section{Conclusions}

We found a very limited number of CCM journals with policies for limiting A-SC. Journals with A-SC policies had higher IF. The J-SC rate was highly variable and greater in journals with narrower focus of interest. Excluding author's and journal's self-referencing from the scientific metrics calculation could be a valuable option to tackle these forms of scientific malpractice.

\section{Abbreviations}

A-SC: Author's self-citation; CCM: Critical care medicine; IF: Impact factor; JSC: Journals' self-citation

\section{Acknowledgements}

NoneEthics approval and consent to participate

Not needed

\section{Authors' contributions}

FS, PM, and MA had the idea to investigate self-citations; ST and AM downloaded the data; FS and AM analyzed the journal-self-citation rate for each journal; FS and ST conducted the statistical analysis comparing journals according to policies and according to their multidisciplinary, broad or narrow interest in the discipline; FS and PM interpreted the data and wrote the initial draft; ST, AM, and MA revised critically the draft. All authors agreed on the final version of the manuscript. The author (s) read and approved the final manuscript.
Funding

None

Availability of data and materials

Available on request and online at the source quoted.

Consent for publication

Not needed

\section{Competing interests}

The authors declare that they have no competing interests.

\section{Author details}

${ }^{1}$ Department of Anaesthesia and Intensive Care, A.O.U., "Policlinico-Vittorio Emanuele" University Hospital, via S. Sofia 78, 95100 Catania, Italy. ${ }^{2}$.School of Anaesthesia and Intensive Care, University Hospital "G. Rodolico", University of Catania, Catania, Italy. ${ }^{3}$ School of Anaesthesia and Intensive Care, Department of Medical and Surgical Sciences, "Magna Graecia" University, Catanzaro, Italy.

Received: 16 December 2020 Accepted: 18 January 2021

Published online: 26 January 2021

References

1. Van Noorden R, Singh Chawla D. Hundreds of extreme self-citing scientists revealed in new database. Nature. 2019;572(7771):578-9.

2. Anaesth Br J. 2021;126(1):e21-5. https://doi.org/10.1016/j.bja.2020.10.002. Epub 2020 Oct 26.

3. Trusted insights and analytics - Clarivate https://jcr.clarivate.com/ JCRJournalHomeAction.action Accessed October 302020

4. "New Research Misconduct Policies"- NSF National Science Foundation https://www.nsf.gov/oig/_pdf/presentations/session.pdf Accessed November 28, 2020

5. Ghost Writing Initiated by Commercial Companies - World Assosiation of Medical Editors website (WAME) WAOME http://wame.org/ghost-writinginitiated-commercial-companies Accessed November 282020

6. Hemmat Esfe M, Wongwises S, Asadi A, Karimipour A, Akbari M. Mandatory and Self-citation; Types, Reasons, Their Benefits and Disadvantages. Sci Eng Ethics. 2015;21(6):1581-5.

7. Tighe P, Rice KJ, Gravenstein N, Rice MJ. Artifactual increase in journal selfcitation. Anesth Analg. 2011;113(2):378-82.

8. Cortegiani A, Longhini F, Sanfilippo F, Raineri SM, Gregoretti C, Giarratano A. Predatory Open-Access Publishing in Anesthesiology. Anesth Analg. 2019; 128(1):182-7.

9. Cortegiani A, Sanfilippo F, Tramarin J, Giarratano A. Predatory open-access publishing in critical care medicine. J Crit Care. 2019;50:247-9.

\section{Publisher's Note}

Springer Nature remains neutral with regard to jurisdictional claims in published maps and institutional affiliations.

Ready to submit your research? Choose BMC and benefit from:

- fast, convenient online submission

- thorough peer review by experienced researchers in your field

- rapid publication on acceptance

- support for research data, including large and complex data types

- gold Open Access which fosters wider collaboration and increased citations

- maximum visibility for your research: over $100 \mathrm{M}$ website views per year

At $\mathrm{BMC}$, research is always in progress.

Learn more biomedcentral.com/submissions 